\title{
Perceptions of a Nearby Exurban Protected Area in South Carolina, USA
}

\author{
Submitted to \\ Environmental Management \\ by \\ Dr. David B. Weaver \\ and \\ Dr. Laura J. Lawton
}

Please change contact details for authors to:

Dept. of Tourism, Leisure, Hotel \& Sport Management

Griffith Business School

Griffith University - Gold Coast Campus

QLD 4222, Australia

Fax: +61-(07)-5552-8507

E-mail: d.weaver@griffith.edu.au 


\begin{abstract}
To help address the dearth of literature on the relations between local residents and high order protected areas near urban areas in the more developed regions, this study examines the perceptions of Columbia (South Carolina) residents toward nearby exurban Congaree National Park (CNP). Mail-out survey results from a random sample of 455 adult residents revealed positive attitudes toward the Park, although this did not extend to a desire to personally volunteer in Park activities. Cluster analysis on the basis of seven perceptual statements produced three groups; 'very enthusiastic park supporters' (VEPS) accounting for one-quarter of the sample, 'less enthusiastic park supporters' (LEPS) accounting for about one-half, and 'ambivalents' (AMBS) accounting for the rest. The AMBS tend to be younger than members of the other clusters and have higher income, but enthusiasm is more clearly related to high levels of CNP interaction and awareness. Managerial implications of the study are considered, including the need to encourage higher levels of Park awareness and visitation among residents of the greater Columbia urban area.
\end{abstract}

Key words: National Parks, Congaree National Park, local community perceptions, ruralurban fringe 


\section{Introduction}

It is increasingly recognized that high order protected areas (i.e., IUCN categories I-III), without public support, will not serve in the long term as entities that effectively safeguard strategically critical ecosystems or portions thereof (McNeely 1990, Miller and Hobbs 2002). As stated by Redford and others (2006, p. 2) "protected areas of all types will not survive without people - inside them, using them in sensible ways, or outside them, respecting them and defending them". This supports Ghimire and Pimbert (1997), who regard protected areas as 'social spaces' which cannot be divorced from their human context. Especially important in this regard are adjacent and nearby residents, who are in a special position to protect - or undermine - nearby higher order protected areas depending on the decisions they make about the use of their own property, the actions they demand from government, the activities they themselves undertake legally or illegally within those protected areas, and the degree to which they choose to oppose, support or ignore the potentially destructive actions of others.

Given this context, it is not surprising that research on the perceptions, attitudes and behavior of local residents has been a major theme in the protected areas management literature since the 1980s, rivaling in magnitude the literature on visitor impacts and perceptions. Most of this research has been conducted within less developed countries (LDCs) and focuses on adjacent residents' access, or lack thereof, to protected area resources. Issues such as alienation and livestock predation dominate this literature, which suggests that local residents support nearby protected areas if the latter continually provides them with tangible and significant benefits (De Boer and Baquete 1998; Walpole and Goodwin 2001; Jim and Xu 2002; Madhusudan 2003; Spiteri and Nepal 
2006; Wang, Lassoie and Curtis 2006). To concurrently achieve conservation and resident objectives, community-based conservation initiatives are recommended (Kellert and others 2000; Mehta and Heinen 2001), in many cases focused on ecotourism (Vincent and Thompson 2002; Jones 2005; Lai and Nepal 2006; Morais and others 2006).

Less attention has been paid to the relationships between local residents and protected areas in the more developed countries (MDCs). In part this is because habitat destruction and other major ecological impacts are not perceived to be as dire, while attitudes are generally assumed to be more positive and actions inside as well as outside of such areas (mainly recreational in character) less destructive. To the extent that MDC settings have been researched, this has tended to focus on the growing phenomenon of amenity migration to the fringes of relatively remote US protected entities such as Yellowstone and Grand Teton National Parks (Rasker 1993; Jobes 2000; Johnson and others 2003; Lynch 2006; Thompson 2006). Similar trends have been investigated in Canada (Chipeniuk 2006; Moore and others 2006), Australia (Buckley and others 2006) and New Zealand (Hall 2006).

One of two major themes in this MDC literature considers the local and regional ecological destabilization arising from attempts by growing numbers of amenity migrants to locate as close as possible to the boundaries of high order protected areas. Such proximity is desirable because it provides ready access to quality recreational opportunities as well as buffer zone against adjacent development (Nelson 1992; Beatley 1994). However, amenity migration exacerbates rural sprawl (or 'rurbanization') despite the paradoxical motivations of many migrants to avoid sprawl in their areas of origin. The second theme focuses on conflicts between amenity migrants and longer-term local 
residents more likely to depend on the primary resource sector and less biocentric in their environmental attitudes and perceptions of nearby protected areas. Jobes (1991) integrates these themes in describing the complex and dynamic network of social and ecological relationships of the Greater Yellowstone area as a social system structured in concentric rings around the focus National Parks. Zone I, within a few miles of the Park boundaries, is an area of tension between long time residents and newcomers, while the Zone II is also a zone of conflict due to the presence of advocacy group headquarters for environmental organizations as well as primary resource industries. Zone III and beyond exert political influences at the state and national level, and provide visitors who meet the definitional criteria of domestic or international tourists.

Almost absent from the MDC literature is consideration of higher order protected area sites in urban, suburban and exurban settings, even though Miller and Hobbs (2002) argue that conservation needs to focus more on areas where large numbers of people actually live. Exurban settings, also described as the 'rural-urban fringe', are especially important. Defined as spaces where land uses exhibit compromise between rural and urban locational advantages (e.g. lower land costs, low taxes, and reduced congestion on one hand, and being within commuting distance to urban employment and amenities on the other) (Nelson 1992), these unstable transitional areas occupy a large and increasing amount of space. In the late 1990s, exurbs may have accounted for as much as one-third of the land area and one-quarter of the population in the coterminous 48 US states (Daniels 1999; Wolf 1999). Characteristic activities that increasingly join and then displace existing farming and forestry activity as ecological degraders include land parcelization for residential and other purposes, predation by domestic or feral dogs and 
cats, noise and air pollution from increased traffic, opportunistic garbage dumping, pesticide drift from residences and golf courses, increased runoff of contaminated water, groundwater contamination from septic beds and lawn applications, vandalism, and colonization by exotic plants (Stenhouse 2004). Potentially more significant, however, are the threats diffusing from nearby areas already urbanized or suburbanized, which usually contain a much higher population than the exurbs. These threats include in situ air pollutants such as ground-level ozone, contaminated and/or excessive runoff, heat island effects, and potentially unsustainable demand for the recreational opportunities afforded by exurban protected areas. Proximity may also have positive impacts, including the potential to build a critical mass of local protected area supporters providing substantial donations, volunteer activity, advocacy group membership, pro-park political pressure, and modifications in personal behavior that reduce ecological stress (Wakefield and others 2006).

These urban and exurban stresses are a matter of growing concern given two factors related to the relationship between higher order protected areas and the ruralurban fringe. First, encroaching exurbanization means that many long established parks in originally rural settings are now located within or contiguous to the rural-urban fringe. This is illustrated by Sydney, Australia, where exurbs now abut almost all of the National Parks that situate in an arc around the greater urban area. In the USA, exurbanization from the Washington DC area and from within the Shenandoah Valley threatens Shenandoah National Park. Other increasingly affected National Parks include Everglades (near Miami), Great Smoky Mountains (Asheville and Knoxville) and Rocky Mountain (Boulder-Fort Collins). 
Second, concerns about urban sprawl and the availability of outdoor recreational opportunities for urban residents, among other factors, have combined recently to prompt the formation or upgrading of high order protected areas near large urban agglomerations. Among the best US examples are the Cuyahoga Valley National Park in Ohio, established in 2000 in a semi-rural pocket between greater Cleveland and Akron, and Joshua Tree National Park, upgraded from a National Monument in 1994, and situated on the edge of the Palm Spring urban agglomeration. Another is Congaree National Park in South Carolina (near the state capital of Columbia and henceforth abbreviated as CNP), the case study for this research (see below). No investigations of resident attitudes toward such US exurban protected areas have been undertaken to date, although Weaver and Lawton (2004) found that the mainly local visitors to the World Heritage-listed National Parks in the rural-urban fringe of Australia's Gold Coast were biocentric and protective of the ecological integrity of these areas. Comparisons to the current study are qualified by the Gold Coast's status as a major domestic and international tourist destination and by the focus in this study on tourism-related aspects of the relationship.

\section{Study Area}

CNP is an $89 \mathrm{~km}^{2}$ tract located on the southeastern edge of the Metropolitan Columbia statistical area, which recorded a population of 690,000 residents in 2005 (US Census Bureau 2006) (Figure 1). The tract, located about 25 kilometers southeast of the Columbia central business district, was sporadically logged until the early $20^{\text {th }}$ century, but remained in private ownership afterwards until the early 1970s when it was acquired by the federal government to eliminate the threat of renewed logging. It was initially 
designated as a National Natural Landmark (IUCN category III) in 1974, a National Monument (IUCN category III) in 1976, and most recently a National Park (IUCN category II) in 2003. The rationale for the latter upgrade included a desire to more rigorously protect one of the largest tracts of relatively undisturbed old growth floodplain forest in North America, exceptionally high levels of biodiversity, and a uniquely tall closed forest canopy. A good indication of this rigor is the Wilderness (IUCN category Ia) sub-designation accorded to $70 \%$ of CNP. Additional evidence of its ecological significance includes concurrent designations as an International Biosphere Reserve and a Globally Important Bird Area (NPS 2006).

(Figure 1 here)

The spatial context of CNP, much like the greater Yellowstone area described by Jobes (1991), can be characterized as a social system consisting of several contiguous zones. The equivalent of Zone III and higher, i.e. the area beyond metropolitan Columbia, accounts for about two-thirds of all CNP visitors (NPS 2005), who numbered 96,000 in 2000 and 134,000 in 2006 (NPS 2007). Zone II consists of Richland and Lexington counties minus the immediately adjacent exurban portions of the Hopkins neighborhood, which constitutes Zone I. Unlike Yellowstone, Columbia's Zone II is heavily urbanized and suburbanized. A major anthropogenic threat from Zone II stems from the fact that the Congaree River inundates most of CNP several times each year and serves as a conduit for urban runoff from most of the Columbia area, which increased in population by $6.6 \%$ (from 647,000 to 690,000) between 2000 and 2005. Zone I, again unlike Yellowstone, is 
not at this time a destination for amenity migrants. Instead, it is an overwhelmingly African-American community of about 6,000 residents characterized by haphazard land uses and high poverty levels. A notable Zone I threat to CNP is the nearby location of the highest priority site on the National Priority List of South Carolina's most contaminated hazardous waste sites (EPA 2006).

\section{Objectives and Rationale}

This exploratory research contributes uniquely to the embryonic literature on the relationship between high order exurban protected areas in MDC settings and nearby urban agglomerations by examining the perceptions held by the residents of the greater Columbia area toward CNP. Residents are divided into distinct groups based on these perceptions, and the groups are differentiated by selected socio-demographic characteristics and the degree of interaction with CNP. The theoretical and managerial implications of these findings are then considered.

As described above, almost all of the perception and interaction literature pertinent to higher order protected areas focus on Zone I (e.g. resource access to local communities in LDCs and amenity migrants in MDCs) or Zone III and higher (e.g. domestic and international tourist-visitors). The uniqueness of the present study is its emphasis on Zone II, that is, the mainly urban and suburban portions of greater Columbia that are associated with an array of potential negative as well as positive impacts on CNP. This emphasis derives from the fact that the Zone I portion of greater Columbia relative to CNP (i.e. exurban Hopkins) accounts for less than one per cent of the area's population, and hence is likely to be only incidentally represented in a randomly selected 
sample of local residents. Sample stratification to substantially over-represent Zone I could skew the cluster solution and was therefore rejected. Given its uniqueness, we contend that this area merits a separate study utilizing intensive fieldwork and an ethnographic approach which considers its affiliation with both LDC and MDC circumstances.

\section{Methodology}

A six-page mail-out survey instrument was designed to solicit the desired information. Individual sections inquire whether the respondent has visited CNP or not (Section A), reasons for not visiting (if applicable) (Section B), reasons for the most recent visit (if applicable) as well as satisfaction with that visit and total number of visits (Section C), perceptions of the relationship between Columbia and CNP (Section D), visits of other household members (Section E) and respondent characteristics, including zip code and length of residence in the Columbia area (Section F). Section D includes ten 5-point Likert-scaled statements (where $1=$ 'strongly disagree', $2=$ 'disagree', $3=$ 'neutral/not sure', 4 = 'agree', 5 = 'strongly agree') about perceptions of CNP, focusing on its relationship with the Columbia urban area and its residents. Being exploratory, the study constructed this set of statements after examining the protected area literature and consulting with expert colleagues.

The intent was to cluster analyze respondents based on these ten items in Section D (or some internally consistent combination thereof based on reliability analysis) and to accept the most logical solution after using multiple discriminant analysis to test the clusters and items for accuracy, as per Hair, Anderson, Tatham and Black (1995). Cluster 
analysis, using Ward's method to maximize intra-group homogeneity and inter-group heterogeneity, is an appropriate technique given the lack of a priori knowledge about the most appropriate number of distinct resident groups or their characteristics (Hair et al. 1995). The technique allows the researcher to request multiple solutions (e.g. two clusters, three clusters, etc.), from which the 'correct' solution is selected based on examination of resultant dendograms, cluster sizes, differences in cluster means, and multiple discriminate analysis results, as well as intuition and knowledge of the investigation topic and target population. The process of selecting the optimal solution, accordingly, is often described as more of an art than a science (source).

Once a solution is accepted (or sometimes as part of the selection process), the clusters are profiled and compared using comparison-of-means tests or chi-squared tests, as warranted, to see whether significant differences exist with regard to other relevant variables solicited in the survey. Following a small-sample pretest to confirm wording and design, the survey was mailed out in early 2006 to a stratified $(50 \%$ male, $50 \%$ female) random sample of 2,500 adult residents of the Columbia metropolitan area. Cases were selected from the most recent edition of the online area telephone directory using random number tables. Limitations of this source include the exclusion of very recent arrivals, those with unlisted numbers, and residents without a land-line telephone, the latter usually being disproportionately African-American and elderly (Sharkey and Haines 2001). An incentive involving a draw for $\$ 500$ was included in the cover letter, inclusion in the draw being contingent upon the respondent completing all parts of the questionnaire. This is a necessary qualification since cluster analysis can only be performed on complete response sets to the items selected for clustering. A reminder 
letter was sent three weeks following the initial mail-out, which included a pre-paid return envelope. Because the reminder letter yielded only about 25 additional returns, no further letters to non-respondents were sent.

\section{Results}

By late March 2006, 455 valid completed surveys were received. This represents an effective response rate of $20.1 \%$ allowing for undeliverable surveys due to incorrect addresses as well as returned surveys that had to be rejected because there were no responses to one or more of the statements in Section D. The absolute sample size, however, is more than adequate for the purposes of conducting a cluster analysis. In at least two respects, the sample did not reflect the demography of the Columbia area. First, African-Americans account for about $28 \%$ of the metropolitan adult population but $14 \%$ of respondents. Second, individuals 25 and older with graduate degrees account for about $9 \%$ of the metropolitan population but almost one-third of respondents (US Census Bureau 2003). Neither variable, however, was a significant cluster differentiator (see below) and this non-response bias therefore probably did not seriously skew the cluster model.

In the first stage of data analysis, Cronbach's Alpha was calculated for all ten perceptual statements in Section D. This yielded a value of .391 which is much lower than the .70 threshold recommended in social science research (Rukert and Churchill 1984). Further examination of the items resulted in the removal of three statements and a recalibrated Cronbach's Alpha value of .792. A range of solutions ranging from two to five categories was computed in the cluster analysis of the remaining seven items, and the 
three-cluster solution stood out as providing the greatest and most intuitively logical differentiation of the sample. Multiple discriminant analysis subsequently showed that all seven variables significantly contributed to cluster differentiation $(p<.001$ for all items as per Wilks' Lambda), while the two resulting discriminant functions were also significant at the same level. In a further indication of reliability, the classification matrix comparing actual cluster membership with predicted membership revealed that $87.3 \%$ and $86.2 \%$ of the original and cross-validated grouped cases respectively were correctly classified.

Table 1 depicts the overall sample and cluster means for the seven statements used in the cluster analysis (i.e. the cluster variate). Positive and biocentric perceptions of CNP are readily apparent in the sample as a whole, especially with regard to the status of the site as an asset to the residents of Columbia and concurrence that potentially harmful nearby land uses should be restricted. There is also overall agreement that area residents have a special responsibility to safeguard CNP and should have opportunities to participate in its protection and enhancement. There is less enthusiasm for the idea that CNG is an important part of the Columbia area's identity or that local residents should have the opportunity to provide input into the CNP planning process. Little interest was expressed in being personally involved as a volunteer in CNP-related activities, this being the only statement to yield an overall mean below 3.00.

(Table 1 here) 
Further analysis of the cluster means reveals a bell-curved sample with relatively homogenous sub-groups of 'very enthusiastic Park supporters' (VEPS) (n=111), 'less enthusiastic Park supporters' (LEPS) $(\mathrm{n}=240)$ and 'ambivalents' (AMBS) $(\mathrm{n}=104)$. The VEPS almost all 'strongly agree' that CNP is an asset to Columbia residents and that the latter have a special responsibility to ensure that its natural assets are protected. They are also the only group to profess a personal interest in volunteering for CNP, though this interest is tepid. For all other items, the AMBS array near the neutral/not sure option of 3.00, with the highest mean expressed for the status of CNP as an asset for area residents (3.54). While all inter-cluster differences are highly significant for the seven clustered variables, the intermediate LEPS group is skewed toward the AMBS on the issue of volunteering and toward the VEPS on the issues of restricting nearby harmful land uses and regarding CNP as an important part of the Columbia area's identity.

Table 1 also depicts the means for the three perception-related statements not included in the cluster analysis, in the interests of contributing to the validation of the selected cluster solution (Aldenderfer and Blashfield 1984). Although one of these statements is not significant at the .05 level, the inter-cluster variations generally corroborate the cluster variate by showing that the AMBS are less likely to regard the existence of CNP as being personally important, to support its further expansion, or to regard the continued growth of the greater Columbia area as a threat. Notably, the VEPS do not overwhelmingly endorse any of these adjunctive perceptual statements.

As depicted in Table 2, household income is the only solicited socio-demographic variable that distinguishes the clusters at the $p<.05$ level, with the AMBS being more likely to have household incomes in excess of $\$ 50,000$. More specifically, $25 \%$ of those 
earning over $\$ 50,000$ are AMBS, compared with $15 \%$ of those earning under $\$ 50,000$. The F-test for age did not meet the same significance threshold, but it does appear that the AMBS are also younger than other respondents, if not resident in the Columbia area for fewer years. Variables that describe respondents' interactions with CNP, in contrast, display strongly significant differences between the clusters (Table 3). The AMBS are far less likely to have already visited CNP, to be aware of its status as a National Park, to be satisfied with their most recent visit, and to have other family members who have already visited CNP. The finding that the much higher level of visitation by the VEPS is not statistically significant may be due simply to the sensitivity of the chi-squared test to the smaller numbers of actual visitors within each cluster (and especially among the AMBS).

(Table 2 here)

(Table 3 here)

\section{Discussion and Conclusion}

The context of this study is that CNP is facing an increasingly precarious ecological future, being a recently created entity with a dominant biocentric focus that is being encroached upon and otherwise affected by potentially harmful land uses and activities associated with the continuing growth of the greater Columbia area. Threats to CNP, moreover, are not confined to contiguous exurban spaces adjacent to CNP boundaries, as demonstrated by the periodic inundations from the Congaree River that deliver runoff and other effluents from almost the entire urban area to most of CNP. Stresses such as urban runoff achieve critical mass through the cumulative actions of individual residents, thus 
suggesting that civic action will become increasingly important to assure environmental sustainability as urban areas continue to expand (Wakefield and others 2006).

Concerted and effective civic action, in turn, requires a critical mass of residents to be sufficiently concerned about local environmental assets such as CNP and the salient stresses that threaten such areas. In this regard, the overall findings of this study are encouraging, with Columbia area residents, like those from the Gold Coast (Weaver and Lawton 2004) regarding CNP as a personal and community asset for which the local community bears a special responsibility despite its federal status. Members of this community may therefore be amenable to modifying their behavior and pressuring municipal authorities to modify their behavior in ways that would benefit the ecology of CNP should appropriate messages to that effect be effectively delivered by CNP authorities or others. This would include the need to educate residents about relevant natural processes such as periodic inundation that implicate various unsustainable but superficially unrelated practices. At the same time, limits to the biocentrism of the local population must be recognized, with 'radical' measures such as further expansions to CNP and the curtailment of Columbia's urban growth unlikely to receive strong support.

A related limitation to the mobilization of local residents is the lack of interest in personally volunteering on behalf of CNP, with just 51 respondents $(11.2 \%$ of the sample) agreeing or strongly agreeing to this statement. Notably, this proportion increases to $22 \%$ among those who have previously visited CNP, which is almost identical to the $21 \%$ of sampled CNP visitors who expressed interest in volunteering in an on-site survey conducted by the National Park Service in 2005 (NPS 2005). Efforts should be made by CNP management to mobilize this one-in-five cohort that is open to 
volunteering, and to investigate recruitment strategies for those not similarly motivated. Notwithstanding this lack of enthusiasm, the overall attitudinal profile further suggests that Columbia area residents might be amenable to making financial contributions to activities, programs and organizations that enhance CNP's ecological integrity. Related educational outreach, however, must also include more basic information about the park, given that one-third of the sample was not even aware of Congaree's upgrade to National Park status.

Among the identified clusters, the VEPS - apparently about one-quarter of the population - still appear to offer the most potential to become active, if not specifically to volunteer or to agitate for 'radical' policy changes. Socio-demographic characteristics, however, do not provide managers with any intuitively logical clues for targeting enthusiasts more generally - fully three-quarters of the sample when VEPS are combined with LEPS, who are significantly older and have lower household incomes than ambivalent residents. More promising are the CNP interaction variables, with prior visitation, satisfaction with the most recent visit, prior visitation by other family members, and probably number of visits all positively related to perceptual enthusiasm. While it may well be that interaction is high because these individuals are enthusiastic, it seems more likely for many or most that exposure fosters increased enthusiasm (Weaver and Lawton 2002). Thus, it may be that residents are concerned and supportive of CNP to the extent that they and/or other household members derive personal enjoyment from use of the site. If so, then CNP managers should consider strategies that will attract the approximately one-half of local adult residents who have never visited, and engage such 
visitors with compelling interpretation that increases awareness of and sensitivity toward various environmental issues (Ham 1992; Ham and Weiler 2002).

Limitations of this exploratory study, which is the first to consider the perceptions that urban (i.e. Zone II) MDC residents have of a nearby high order protected area, include a disappointing response rate and under-representation of African-Americans and persons without graduate degrees. As well, incidental representation of residents from the exurban portions of the Hopkins neighborhood in the sample prevented any conclusions from being drawn about the perceptions of residents in Zone I of CNP, which we believe warrants a separate study because of its relatively small size and geographic differentiation from the rest of the greater Columbia area. As for appropriate research directives, ongoing issues of reliability, validity and generalization are best addressed by testing the seven-item variate in US urban areas such as Palm Springs and Akron, and in related Australian settings such as Sydney and the Gold Coast.

\section{Literature cited}

Aldenderfer, M. and Blashfield, R. 1984. Cluster analysis. Sage University Series on Quantitative Applications in the Social Sciences, No. 44. Sage, Newbury Park.

Beatley, T. 1994. Habitat conservation planning: Endangered species and urban growth. University of Texas Press, Austin, TX, USA. 
Buckley, R., N. Sander, C. Ollenburg, and J. Warnken. 2006. Green change: Inland amenity migration in Australia. Pages 278-294 in L.A. Moss (ed.) The amenity migrants: seeking and sustaining mountains and their cultures. CABI, Wallingford, UK.

Chipeniuk, R. 2006. Planning for amenity migration in communities of the British Columbia hinterland. Pages 163-174 in L.A. Moss (ed.) The amenity migrants: seeking and sustaining mountains and their cultures. CABI, Wallingford, UK.

Daniels, T. 1999. When city and country collide: managing growth in the metropolitan fringe. Island Press, Washington, DC.

De Boer, W. and Baquete, D. 1998. Natural resource use, crop damage, and attitudes of rural people in the vicinity of the Maputo Elephant Reserve, Mozambique. Environmental Conservation 25:208-218.

EPA (Environmental Protection Agency). 2006. NPL Site Narrative for SCRDI Bluff Road. http://www.epa.gov/superfund/sites/npl/nar475.htm (visited 2 February 2007).

Ghimire, K. and Pimbert, M. (eds.) 1997. Social change and conservation: Environmental politics and impacts of national parks and protected areas. Earthscan, London.

Hair, J., Anderson, R., Tatham, R. and Black, W. 1995. Multivariate data analysis. $4^{\text {th }}$ Edition. Prentice-Hall, Englewood Cliffs, NJ. 
Hall, C. M. 2006. Amenity migration in the South Island of New Zealand: Contestation for land and landscape in Central Otago. Pages 295-305 in L.A. Moss (ed.) The amenity migrants: seeking and sustaining mountains and their cultures. CABI, Wallingford, UK.

Ham, S. 1992. Environmental interpretation. North American Press, Golden, CO.

Ham, S. and Weiler, B. 2002. Interpretation as the centerpiece of sustainable wildlife tourism. Pages 35-44 in R. Harris, T. Griffin and P. Williams (eds.) Sustainable tourism: A global perspective. Elsevier, Oxford.

Jim, and Xu, 2002. Stifled Stakeholders and Subdued Participation: Interpreting Local Responses Toward Shimentai Nature Reserve in South China. Environmental Management 30:327-341.

Jobes, P.C. 2000. Moving nearer to heaven: The illusions and disillusions of migrants to scenic rural places. Praeger, Westport, CN, USA.

Jobes, P.C. 1991. The Greater Yellowstone social system. Conservation Biology 5:387394. 
Johnson, J., B. Maxwell, and R. Aspinall. 2003. Moving nearer to heaven: Growth and change in the Greater Yellowstone Region, USA. Pages 77-88 in R. Buckley, C. Pickering and D.B. Weaver (eds.) Nature-based tourism, environment and land management. CABI, Wallingford, UK.

Jones, S. 2005. Community-based ecotourism - the significance of social capital. Annals of Tourism Research 32:303-324.

Kellert, S., Mehta, J., Ebbin, S. and Lichtenfeld, L. 2000. Community natural resource management: Promise, rhetoric, and reality. Society and Natural Resources 13:705-715.

Lai, P. and Nepal, S. 2006. Local perspectives of ecotourism development in Tawushan Nature Reserve, Taiwan. Tourism Management 27:1117-1129.

Lynch, M. 2006. 'Too much love?': The environmental and community impacts of amenity migrants on Jackson Hole, Wyoming. Pages 94-107 in L.A. Moss (ed.) The amenity migrants: seeking and sustaining mountains and their cultures. CABI, Wallingford, UK.

Madhusudan, M. 2003. Living amidst large wildlife: Livestock and crop depredation by large mammals in the interior villages of Bhadra Tiger Reserve, South India. Environmental Management 31:466-475. 
McNeely, J.A. 1990. The future of National Parks. Environment 32(1):16-20, 36-41.

Mehta, J. and Heinen, J. 2001. Does community-based conservation shape favorable attitudes among locals? An empirical study from Nepal. Environmental Management 28:165-177.

Miller, J.R. and R.J. Hobbs. 2002. Conservation where people live and work. Conservation Biology 16:330-337.

Moore, S., Williams, P. and Gill, A. 2006. Finding a pad in paradise: Amenity migratin effects on Whistler, British Columbia. Pages 135-147 in L.A. Moss (ed.) The amenity migrants: seeking and sustaining mountains and their cultures. CABI, Wallingford, UK.

Morais, D., Zhu C., Dong E. and Yang G. 2006. Promoting sustainability through increased community involvement: the Shangri-La Ecotourism Demonstration Project. Tourism Review International 10:131-140.

NPS (National Park Service). 2005. Congaree National Park visitor study spring 2005. http://www.psu.uidaho.edu/files/usp/reports/163_CONG_rept.pdf (visited 28 June 2007).

NPS (National Park Service). 2006. Congaree National Park South Carolina. http://www.nps.gov/cosw/ (visited 2 February 2007). 
NPS (National Park Service). 2007. Visitation statistics. http://www2.

nature.nps.gov/stats/ (visited 28 June 2007).

Nelson, A. 1992. Characterizing exurbia. Journal of Planning Literature 6:350-368.

Rasker, R. 1993. Rural development, conservation and public policy in the Greater Yellowstone ecosystem. Society and Natural Resources 6:109-126.

Redford, K.H., J.G. Robinson, and W.M. Adams. 2006. Parks as shibboleths. Conservation Biology 20:1-2.

Rukert, R. and Churchill, G. 1984. Reliability and validity of alternative measures of channel member satisfaction. Journal of Marketing Research 21: 226-233.

Sharkey, J. and Haines, P. 2001. The feasibility of using a telephone-administered survey for determining nutritional service needs of noninstitutionalized older adults in rural areas: time and costs. The Gerontologist 41: 546-552.

Spiteri, A. and Nepal, S. 2006. Incentive-based conservation programs in developing countries: A review of some key issues and suggestions for improvement. Environmental Management 37:1-14. 
Stenhouse, R.N. 2004. Local government conservation and management of native vegetation in urban Australia. Environmental Management 34:209-222.

Thompson, S. 2006. Gateway to Glacier: Will amenity migrants in north-western Montana lead the way for amenity conservation? Pages 108-119 in L.A. Moss (ed.) The amenity migrants: seeking and sustaining mountains and their cultures. CABI, Wallingford, UK.

US Census Bureau. 2003. Columbia, SC MSA. http://www.census.gov/acs/www/Products/Profiles/Single/2003/ACS/Tabular/380/38000 US17602.htm (visited 10 February 2007).

US Census Bureau. 2006. Cumulative estimates of population change for metropolitan statistical areas and rankings: April 12000 to July 12005. http://www.census.gov/population/www/estimates/metropop/2005/cbsa-07-fmt.xls (visited 4 February 2007).

Vincent, V. and Thompson, W. 2002. Assessing community support and sustainability for ecotourism development. Journal of Travel Research 41:153-160.

Wakefield, S., S. Elliott, J. Eyles, and D. Cole. 2006. Taking environmental actions: The role of local composition, context, and collective. Environmental Management 37:40-53. 
Walpole, M. and Goodwin, H. 2001. Local attitudes towards conservation and tourism around Komodo National Park, Indonesia. Environmental Conservation 28:160-166.

Wang, S., Lassoie, J. and Curtis, P. 2006. Farmer attitudes towards conservation in Jigme Singye Wangchuck National Park, Bhutan. Environmental Conservation 33:148-156.

Weaver, D. and Lawton, L. 2002. Overnight ecotourist market segmentation in the Gold Coast hinterland of Australia. Journal of Travel Research 40: 270-280.

Weaver, D. and Lawton, L. 2004. Visitor attitudes toward tourism development and product integration in an Australian urban-rural fringe. Journal of Travel Research 42:286-296.

Wolf, P. 1999. Hot towns: the future of the fastest growing communities in America. Rutgers University Press, New Brunswick, NJ, USA. 
Table 1: Congaree National Park perception statements: Means ${ }^{1}$ for three cluster solution

\begin{tabular}{|c|c|c|c|c|}
\hline Item & $\begin{array}{l}\text { Overall } \\
\text { mean } \\
\mathrm{n}= \\
455\end{array}$ & $\begin{array}{c}\text { Very } \\
\text { enthusiastic } \\
\text { Park } \\
\text { supporters } \\
\text { (VEPS) } \\
\mathrm{n}=111\end{array}$ & $\begin{array}{c}\text { Less } \\
\text { enthusiastic } \\
\text { Park } \\
\text { supporters } \\
\text { (LEPS) } \\
\mathrm{n}=240\end{array}$ & $\begin{array}{l}\text { Ambivalents } \\
\text { (AMBS) } \\
\mathrm{n}=104\end{array}$ \\
\hline $\begin{array}{l}\text { *Congaree National Park is an asset for the } \\
\text { residents of the Columbia area. }{ }^{2}\end{array}$ & 4.30 & 4.94 & 4.33 & 3.54 \\
\hline $\begin{array}{l}\text { *Land uses in areas near Congaree National } \\
\text { Park that could potentially harm the park } \\
\text { should be restricted. }\end{array}$ & 4.28 & 4.78 & 4.44 & 3.37 \\
\hline $\begin{array}{l}\text { * Residents of the Columbia area have a special } \\
\text { responsibility to ensure that the natural } \\
\text { resources of Congaree National Park are } \\
\text { protected. }\end{array}$ & 4.12 & 4.95 & 4.16 & 3.14 \\
\hline $\begin{array}{l}* \text { Residents of the Columbia area should have } \\
\text { opportunities to participate in activities that } \\
\text { protect and enhance the natural resources of } \\
\text { Congaree National Park. }\end{array}$ & 4.09 & 4.73 & 4.13 & 3.35 \\
\hline $\begin{array}{l}\text { *Congaree National Park is an important part } \\
\text { of the identity of the Columbia area. }{ }^{2}\end{array}$ & 3.91 & 4.60 & 4.10 & 2.73 \\
\hline $\begin{array}{l}\text { The existence of Congaree National Park is } \\
\text { important to me. }\end{array}$ & 3.88 & 4.03 & 4.03 & 3.37 \\
\hline $\begin{array}{l}\text { * Residents of the Columbia area should have } \\
\text { the opportunity to provide input into the } \\
\text { planning of Congaree National Park. }{ }^{2}\end{array}$ & 3.64 & 4.16 & 3.61 & 3.13 \\
\hline $\begin{array}{l}\text { The continued growth of the greater Columbia } \\
\text { area poses a threat to Congaree National Park. }{ }^{3}\end{array}$ & 3.38 & 3.53 & 3.40 & 3.17 \\
\hline $\begin{array}{l}\text { Congaree National Park should be expanded } \\
\text { further. }{ }^{2}\end{array}$ & 3.27 & 3.69 & 3.21 & 2.97 \\
\hline $\begin{array}{l}\text { *Being a volunteer for Congaree National Park } \\
\text { is something that personally interests me. }{ }^{2}\end{array}$ & 2.26 & 3.45 & 1.94 & 1.71 \\
\hline
\end{tabular}

\footnotetext{
${ }^{1}$ Based on response options $5=$ 'strongly agree', $4=$ 'agree', $3=$ 'neutral $/$ not sure', $2=$ 'disagree', 1 = 'strongly disagree'

${ }^{2}$ Inter-cluster differences significant at $p<.001$

${ }^{3}$ Inter-cluster differences significant at $p<.062$
} 
Table 2: Socio-demographic characteristics of survey respondent sample and clusters (three cluster solution)

\begin{tabular}{|c|c|c|c|c|c|c|}
\hline Variable & $\begin{array}{c}\text { Sample } \\
\mathrm{n}= \\
455\end{array}$ & $\begin{array}{c}\text { Very } \\
\text { enthusiastic } \\
\text { Park } \\
\text { supporters } \\
\text { (VEPS) } \\
\mathrm{n}=111\end{array}$ & $\begin{array}{c}\text { Less } \\
\text { enthusiastic } \\
\text { Park } \\
\text { supporters } \\
\text { (LEPS) } \\
\mathrm{n}=240\end{array}$ & $\begin{array}{c}\text { Ambivalents } \\
\text { (AMBS) } \\
n=104\end{array}$ & test value & $p$ \\
\hline Sex: Male \% & $\begin{array}{c}53.7 \\
(100)^{1}\end{array}$ & $\begin{array}{c}52.7 \\
(24.0)\end{array}$ & $\begin{array}{c}51.5 \\
(50.8)\end{array}$ & $\begin{array}{l}59.8 \\
(25.2)\end{array}$ & $\chi^{2}=$ & \\
\hline Female $\%$ & $\begin{array}{l}46.3 \\
(100)\end{array}$ & $\begin{array}{l}47.3 \\
(24.9)\end{array}$ & $\begin{array}{c}48.5 \\
(55.5)\end{array}$ & $\begin{array}{c}40.2 \\
(19.6)\end{array}$ & 2.050 & .359 \\
\hline Race: White \% & $\begin{array}{l}85.7 \\
(100)\end{array}$ & $\begin{array}{l}84.0 \\
(23.9)\end{array}$ & $\begin{array}{c}87.0 \\
(53.6)\end{array}$ & $\begin{array}{l}84.8 \\
(22.5)\end{array}$ & & \\
\hline Black \% & $\begin{array}{l}14.3 \\
(100)\end{array}$ & $\begin{array}{l}16.0 \\
(27.4)\end{array}$ & $\begin{array}{c}13.0 \\
(48.4)\end{array}$ & $\begin{array}{c}15.2 \\
(24.2)\end{array}$ & $\chi^{2}=.617$ & .735 \\
\hline Age (years) & 51.9 & 53.7 & 52.3 & 49.2 & $F=2.693$ & .069 \\
\hline $\begin{array}{l}\text { Length of residence } \\
\text { (years) }\end{array}$ & 28.7 & 30.5 & 28.6 & 27.1 & $F=.814$ & .444 \\
\hline \multicolumn{7}{|l|}{ Education $(\%)$ : } \\
\hline No grad. Degree & $\begin{array}{l}67.6 \\
(100)\end{array}$ & $\begin{array}{l}68.6 \\
(24.2)\end{array}$ & $\begin{array}{c}65.4 \\
(52.0)\end{array}$ & $\begin{array}{c}71.7 \\
(23.8)\end{array}$ & & \\
\hline Grad. Degree & $\begin{array}{l}32.4 \\
(100)\end{array}$ & $\begin{array}{c}31.4 \\
(23.1)\end{array}$ & $\begin{array}{c}34.6 \\
(57.3)\end{array}$ & $\begin{array}{c}28.3 \\
(19.6)\end{array}$ & $\chi^{2}=1.334$ & .513 \\
\hline \multicolumn{7}{|l|}{ Household income: } \\
\hline$<\$ 50 \mathrm{~K} \%$ & $\begin{array}{l}34.9 \\
(100)\end{array}$ & $\begin{array}{l}39.8 \\
(27.9)\end{array}$ & $\begin{array}{c}37.2 \\
(57.1)\end{array}$ & $\begin{array}{c}23.9 \\
(15.0)\end{array}$ & $\chi^{2}=6.489$ & .039 \\
\hline$>\$ 50 \mathrm{~K} \%$ & $\begin{array}{l}65.1 \\
(100)\end{array}$ & $\begin{array}{c}60.2 \\
(22.6)\end{array}$ & $\begin{array}{c}62.8 \\
(51.8)\end{array}$ & $\begin{array}{c}76.1 \\
(25.5)\end{array}$ & & \\
\hline
\end{tabular}

1 Number in parentheses describes the percentage of that group (e.g. Males, Graduate Degree holders) within each group. 
Table 3: Congaree National Park interaction characteristics of survey respondent sample and clusters (three cluster solution)

\begin{tabular}{|c|c|c|c|c|c|c|}
\hline Variable & $\begin{array}{l}\text { Sample } \\
\mathrm{N}=455\end{array}$ & $\begin{array}{c}\text { Very } \\
\text { enthusiastic } \\
\text { Park } \\
\text { supporters } \\
\text { (VEPS) } \\
\mathrm{n}=111\end{array}$ & $\begin{array}{c}\text { Less } \\
\text { enthusiastic } \\
\text { Park } \\
\text { supporters } \\
\text { (LEPS) } \\
\mathrm{n}=240\end{array}$ & $\begin{array}{c}\text { Ambivalents } \\
\text { (AMBS) } \\
n=104\end{array}$ & test value & $p$ \\
\hline Prior visit to Park? Yes \% & 52.2 & 65.5 & 53.8 & 34.6 & \multirow[t]{2}{*}{$\chi^{2}=20.872$} & \multirow[t]{2}{*}{.000} \\
\hline No $\%$ & 47.8 & 34.5 & 46.2 & 65.4 & & \\
\hline $\begin{array}{l}\text { Total \# of visits to CNP } \\
\text { for those having already } \\
\text { visited }\end{array}$ & 4.55 & 6.07 & 3.98 & 3.34 & $F=2.033$ & .133 \\
\hline \multicolumn{7}{|l|}{ Awareness of NP status } \\
\hline Yes $\%$ & 67.7 & 73.4 & 69.9 & 56.7 & \multirow[t]{2}{*}{$\chi^{2}=7.869$} & \multirow[t]{2}{*}{.020} \\
\hline No $\%$ & 32.3 & 26.6 & 30.1 & 43.3 & & \\
\hline $\begin{array}{l}\text { Satisfaction with most } \\
\text { recent Park visit (mean out } \\
\text { of } 5.00 \text { ) }\end{array}$ & 4.49 & $4.72^{1}$ & $4.51^{1}$ & 3.94 & $F=15.741$ & .000 \\
\hline \multicolumn{7}{|l|}{ Other family members } \\
\hline have visited: Yes \% & 46.1 & 59.5 & 45.5 & 33.0 & \multirow{2}{*}{$\chi^{2}=15.106$} & \multirow[t]{2}{*}{.001} \\
\hline No $\%$ & 53.9 & 40.5 & 54.5 & 67.0 & & \\
\hline
\end{tabular}

\footnotetext{
${ }^{1}$ means for VEPS and LEPS clusters not significantly different
} 